\title{
Effect of the simultaneous presence of sodium and potassium cations on the
}

\section{hydrothermal synthesis of MCM-22 zeolite}

Efeito da presença simultânea dos cátions sódio e potássio na síntese hidrotérmica da zeólita MCM22

Efecto de la presencia simultánea de cationes sodio y potasio sobre la síntesis hidrotermal de la zeolita MCM-22

\author{
Paulo Henrique Leite Quintela \\ ORCID: https://orcid.org/0000-0003-0881-0852 \\ Federal University of Sergipe, Brazil \\ E-mail: pauloquintela@academico.ufs.br \\ Wellington Siqueira Lima \\ ORCID: https://orcid.org/0000-0002-1157-6422 \\ Federal University of Campina Grande, Brazil \\ E-mail:wsl_20@yahoo.com.br \\ Bruno José Barros da Silva \\ ORCID: https://orcid.org/0000-0002-0297-9588 \\ Federal University of Alagoas, Brazil \\ E-mail: brunojbarros@hotmail.com \\ Antonio Osimar Sousa da Silva \\ ORCID: https://orcid.org/0000-0002-6524-8571 \\ Federal University of Alagoas, Brazil \\ E-mail: antonio.silva@ctec.ufal.br \\ Meiry Gláucia Freire Rodrigues \\ ORCID: https://orcid.org/0000-0003-2258-4230 \\ Federal University of Campina Grande, Brazil \\ E-mail: meiry.rodrigues@ufcg.edu.br
}

\begin{abstract}
The hydrothermal synthesis of MCM-22 zeolite was investigated in reaction systems with different proportions of sodium and potassium cations. The potassium content $\mathrm{R}$, defined as the molar ratio between potassium and the total inorganic cations amounts in the synthesis mixture, varied from 0 to 0.9 , keeping constant the cationic concentration and the alkalinity of the system. The materials were characterized by X-ray diffraction (XRD), $\mathrm{N}_{2}$ adsorption/desorption and scanning electron microscopy (SEM). The $\mathrm{K}^{+}$ions favored the formation of MCM- 22 when $45 \%$ of sodium was replaced by potassium, reducing the time required to synthesize the MCM-22(P) precursor and producing more crystalline samples. Furthermore, the relative amounts of $\mathrm{Na}^{+}$and $\mathrm{K}^{+}$ions remarkably affected the morphology and particle size of the samples. The use of higher potassium contents $(R=0.68-0.9)$ hindered the crystallization of MCM-22 zeolite. Thus, the use of reaction mixtures with adequate proportions of $\mathrm{Na}^{+}$and $\mathrm{K}^{+}$can be an effective strategy to produce highly crystalline samples in shorter times, reducing the cost of synthesis of such zeolite
\end{abstract}

Keywords: Zeolite; Hydrothermal synthesis; MCM-22; Alkali cations.

\section{Resumo}

A síntese hidrotérmica da zeólita MCM-22 foi investigada em sistemas reacionais contendo diferentes proporções de cátions sódio e potássio. O teor de potássio R, definido como a razão molar entre a quantidade de potássio e o total de cátions inorgânicos na mistura reacional, variou entre 0 e 0,9 , mantendo-se constantes a concentração catiônica e a alcalinidade das misturas reacionais. Os materiais foram caracterizados por difratometria de raios X (DRX), adsorção/dessorção física de $\mathrm{N}_{2}$ e microscopia eletrônica de varredura (MEV). Os íons $\mathrm{K}^{+}$favoreceram a formação da MCM-22 quando se substituiu 45\% do sódio por potássio, reduzindo o tempo necessário para sintetizar o precursor MCM-22(P) e produzindo amostras mais cristalinas. Além disso, a quantidade relativa dos íons $\mathrm{Na}^{+} \mathrm{e} \mathrm{K}^{+}$afetou significativamente a morfologia e o tamanho de partícula das amostras. O emprego de teores de potássio mais elevados $(\mathrm{R}=0,68-0,9)$ inibiu a cristalização da zeólita MCM-22. Desta forma, o uso de misturas reacionais com proporções adequadas de $\mathrm{Na}^{+}$e $\mathrm{K}^{+}$pode representar uma estratégia eficaz para produzir amostras altamente cristalinas em tempos mais curtos, reduzindo o custo de síntese da referida zeólita.

Palavras-chave: Zeólita; Síntese hidrotérmica; MCM-22; Cátions alcalinos. 


\section{Resumen}

La síntesis hidrotermal de la zeolita MCM-22 se investigó en sistemas de reacción que contenían diferentes proporciones de cationes de sodio y potasio. El contenido de potasio R, definido como la relación molar entre la cantidad de potasio y los cationes inorgánicos totales en la mezcla de reacción, varió entre 0 y 0,9 , manteniendo constante la concentración catiónica y la alcalinidad de las mezclas de reacción. Los materiales se caracterizaron por difracción de rayos $\mathrm{X}$ (DRX), adsorción/desorción física de $\mathrm{N}_{2}$ y microscopía electrónica de barrido (MEB). Los iones $\mathrm{K}^{+}$favorecieron la formación de MCM-22 cuando el $45 \%$ del sodio fue reemplazado por potasio, reduciendo el tiempo necesario para sintetizar el precursor $\mathrm{MCM}-22(\mathrm{P})$ y produciendo muestras más cristalinas. Además, la cantidad relativa de iones de $\mathrm{Na}^{+}$y $\mathrm{K}^{+}$afectó significativamente la morfología y el tamaño de partícula de las muestras. El uso de mayores contenidos de potasio $(\mathrm{R}=0,68-0,9)$ inhibió la cristalización de la zeolita MCM-22. Por tanto, el uso de mezclas de reacción con proporciones adecuadas de $\mathrm{Na}^{+}$y $\mathrm{K}^{+}$puede representar una estrategia eficaz para producir muestras altamente cristalinas en tiempos más cortos, reduciendo el costo de síntesis de esta zeolita.

Palabras clave: Zeolita; Síntesis hidrotermal; MCM-22; Cationes alcalinos.

\section{Introduction}

Zeolites are crystalline aluminosilicates containing channels and cavities with regular dimensions in the micropore range (Fechete et al., 2012; Li \& Yu, 2021). These materials have a unique combination of properties, such as cation exchange capacity, thermal and hydrothermal stability, selective adsorption and acidity, making them widely used as cation exchangers, adsorbents and catalysts in petroleum and petrochemical industries (Davis, 2014; Khaleque et al., 2020; Shi et al., 2015a).

The hydrothermal synthesis of zeolites is a complex process influenced by several factors, such as reaction mixture composition, nature of the reactants, synthesis temperature and time, types of inorganic cations and organic structure-directing agents, which can modify the kinetics of the crystallization process and the zeolitic structure formed (Nishi \& Thompson, 2002). Normally the synthesis is carried out from mixtures having a single type of inorganic cation, in most cases sodium. However, it is known that the introduction of a second cationic species (generally potassium) may in some situations affect, for instance, the crystallization rate, crystallinity, purity and particle size of the samples (Camblor \& Pérez-Pariente, 1991; Ko \& Ahn, 2004; Suzuki et al., 2009).

MCM-22 is a synthetic zeolite that presents a very peculiar topology (MWW code), whose crystallization occurs by the formation of a lamellar precursor commonly identified as MCM-22(P) (Lawton et al., 1996; Roth et al., 2013). The threedimensional structure of MCM-22 is completed only after calcination, which promotes the removal of the organic template, and the interconnection between the monolayers via condensation of the terminal silanol groups (Díaz et al., 2006).

The MCM-22 zeolite porous system comprises two independent channel networks, both accessible through 10membered ring openings: the first consists of sinusoidal channels with dimensions of $0.41 \mathrm{x} 0.51 \mathrm{~nm}$, and the second is composed of supercages with diameter of $0.71 \mathrm{~nm}$ and height of $1.82 \mathrm{~nm}$ accessed through $0.4 \mathrm{x} 0.55 \mathrm{~nm}$ windows (Laredo et al., 2013). Furthermore, the external surface of the crystals contains 12-ring pockets with apertures of $0.71 \mathrm{~nm}$ and approximate depth of $0.7 \mathrm{~nm}$ (Lawton et al., 1998). This unusual structure enables MCM-22 to exhibit a versatile catalytic behaviour, which has allowed its commercial application in benzene alkylation processes (Degnan, 2007).

Zeolite MCM-22 has been synthesized from mixtures containing only one type of alkali-metal cation, in most cases sodium (Corma et al., 1995; Güray et al., 1999; Wu et al., 2009). Some publications have shown that the MWW topology can be obtained by replacing sodium by potassium, but the effects of such modification on the crystallization kinetics have been divergent in some cases. Wu et al. (2008) showed that the complete replacement of $\mathrm{Na}^{+}$ions by $\mathrm{K}^{+}$decreased the induction period and, consequently, the time required to complete the crystallization under static conditions. Similar results were obtained in fluoride medium and stirred system (Aiello et al., 2000). On the other hand, Vuono et al. (2006) observed longer induction periods when potassium was the only alkali metal present in the synthesis gel in stirring conditions. These 
observations clearly show that the effect of $\mathrm{K}^{+}$ions on the MCM-22 crystallization process depends on the interaction with other experimental parameters.

Although zeolites preparation from mixtures containing two types of inorganic cations is a well-known practice, there are no studies in the open literature analyzing the effects of the simultaneous presence of sodium and potassium on MCM-22 formation. In this context, the aim of this paper was to systematically investigate the MCM-22 zeolite synthesis from reaction mixtures with different proportions of $\mathrm{Na}^{+}$and $\mathrm{K}^{+}$ions, comparing the crystallization kinetics and the textural and morphological properties of the obtained materials.

\section{Methodology}

\subsection{Synthesis}

Zeolite MCM-22 was synthesized by the hydrothermal method under static conditions. The following reagents were used in the experiments: sodium hydroxide (99\%, Riedel-de Haën), potassium hydroxide (85\%, Synth), aluminum hydroxide (50-57\% $\mathrm{Al}_{2} \mathrm{O}_{3}$, Aldrich), hexamethyleneimine (99\%, Aldrich), colloidal silica (40\% $\mathrm{SiO}_{2}$, Aldrich) and distilled water.

The composition and preparation procedure of the reaction mixture were based on the method proposed by Wu et al. (2008), in which MCM-22 zeolite was crystallized from gels containing only sodium as alkali-metal cation. The reactants were added in order to produce mixtures with the following molar composition:

$$
\text { 2,7[(1-R) } \left.\mathrm{Na}_{2} \mathrm{O}+\mathrm{RK}_{2} \mathrm{O}\right]: \mathrm{Al}_{2} \mathrm{O}_{3}: 30 \mathrm{SiO}_{2}: 15 \mathrm{HMI}: 1050 \mathrm{H}_{2} \mathrm{O}
$$

The potassium content $\mathrm{R}$, defined as the molar ratio between the potassium and the total inorganic cations amounts in the synthesis mixture $(\mathrm{R}=\mathrm{K} /(\mathrm{Na}+\mathrm{K}))$, ranged from 0 to 0.9 . Thus, the cationic concentration and alkalinity of the system remained constant.

The mixtures were prepared as follows: at room temperature $\left(\sim 25^{\circ} \mathrm{C}\right)$, the alkali metal source $(\mathrm{NaOH}$ and/or $\mathrm{KOH})$ was dissolved in the total amount of distilled water during $15 \mathrm{~min}$, and then aluminum hydroxide was gradually added. After 15 min, hexamethyleneimine was added dropwise into the mixture. Finally, colloidal silica was added and the resulting mixture was aged at room temperature for $24 \mathrm{~h}$, under magnetic stirring. After the aging period, the mixture was transferred to $70 \mathrm{~mL}$, Teflon-lined, stainless steel autoclaves and heated in a forced air circulation oven at $150{ }^{\circ} \mathrm{C}$.

The autoclaves were removed from the oven at predetermined times (4, 6, 8 or 10 days) and cooled to room temperature under tap water. Subsequently, the solid material was separated from the liquid phase by vacuum filtration and washed with distilled water until the $\mathrm{pH}$ of the filtrate was below 8 . The solids obtained were dried overnight in an oven at $60{ }^{\circ} \mathrm{C}$. Calcination of the as-synthesized samples was carried out in a muffle furnace, where the materials were heated to $550{ }^{\circ} \mathrm{C}$ with a heating rate of $5^{\circ} \mathrm{C} / \mathrm{min}$, and then kept under these conditions for $6 \mathrm{~h}$.

\subsection{Characterization}

$\mathrm{X}$-ray diffraction $(\mathrm{XRD})$ patterns of the synthesized materials were obtained by the powder method on a Shimadzu XRD-6000 diffractometer, with $\mathrm{CuK} \alpha$ radiation, $\mathrm{Ni}$ filter, at $40 \mathrm{kV}$ and $30 \mathrm{~mA}$. The data acquisition was performed in the $2 \theta$ range between 2 and $40^{\circ}$, with scan speed of $2 \%$ min and step of $0.02^{\circ}$. The relative crystallinity was calculated by dividing the total area of the characteristic peaks appearing at $24-28^{\circ} 2 \theta$ by the total area of the same peaks for the reference sample, according to equation 1. The MCM-22 material with the highest total area of the selected peaks was chosen as reference. 


$$
\text { Relative crystallinity }(\%)=\frac{\sum \text { characteristic peaks area }(\text { sample })}{\sum \text { characteristic peaks area }(\text { reference sample) }} \times 100
$$

The textural properties of selected MCM-22 samples were measured by $\mathrm{N}_{2}$ adsorption/desorption at $-196{ }^{\circ} \mathrm{C}$ using a Micromeritics ASAP 2020 equipment. Prior to the analysis, the calcined materials were pretreated at $200{ }^{\circ} \mathrm{C}$ under vacuum $\left(15 \mu \mathrm{mHg}\right.$ ) for $16 \mathrm{~h}$ to remove moisture and other impurities physisorbed on the samples surface. The $\mathrm{N}_{2}$ adsorption/desorption isotherms were obtained in the relative pressures range $\left(\mathrm{P} / \mathrm{P}_{0}\right)$ between 0.05 and 0.99 . The BET method was applied to estimate the total surface area $\left(\mathrm{A}_{\mathrm{BET}}\right)$ for comparative purposes. The t-plot method was used to calculate the external surface area $\left(\mathrm{A}_{\mathrm{ext}}\right)$ and the micropore volume $\left(\mathrm{V}_{\text {micro }}\right)$. The total pore volume $\left(\mathrm{V}_{\text {total }}\right)$ was estimated from the amount of nitrogen adsorbed at the relative pressure of 0.98 , and the mesopore volume $\left(\mathrm{V}_{\text {meso }}\right)$ was defined as the difference between the total and the micropore volumes.

Scanning electron microscopy (SEM) was used to determine crystals size and shape of selected MCM-22 samples. The micrographs were obtained on a TESCAN VEGA3 microscope operating at $20 \mathrm{kV}$. The sample preparation procedure consisted of dispersing a small amount of the solids in acetone and depositing a droplet of the suspension onto an aluminum sample holder. Then, a thin layer of gold was deposited on the sample to improve its conductivity.

\section{Results and Discussion}

\subsection{Effect of sodium and potassium cations on the crystallization process}

The XRD patterns of the samples prepared with different crystallization times from the reaction mixture in which sodium was the only type of alkali metal present $(R=0)$ are shown in Figure 1a. After 4 days, the appearance of the first diffraction peaks was observed, indicating the beginning of the formation of crystalline material. The sample obtained on the sixth day of crystallization exhibited the typical MCM-22(P) lamellar precursor diffractogram, containing mostly broad and overlapped peaks, but also well-defined peaks located in the $2 \theta$ regions of $6.5-7.5^{\circ}$ and $24.5-26^{\circ}$ (Lawton et al., 1996). Further increase in time did not cause a significant increment in the peak intensities, indicating that within 6 days crystallization was almost complete. No contaminant phases were detected in the time interval analyzed.

Figure $1 \mathrm{~b}$ shows the XRD patterns of the samples synthesized with the substitution of $22 \%$ (on a molar basis) of the sodium of the reaction mixture for potassium $(\mathrm{R}=0.22)$. It can be observed that such modification did not significantly alter the MCM-22(P) synthesis process, since the diffraction peaks are slightly more intense than those produced with the exclusive use of sodium, for a same crystallization time. 
Figure 1. XRD patterns of samples synthesized from reaction mixtures with different potassium contents: (a) $R=0$ and (b) $\mathrm{R}=0.22$.
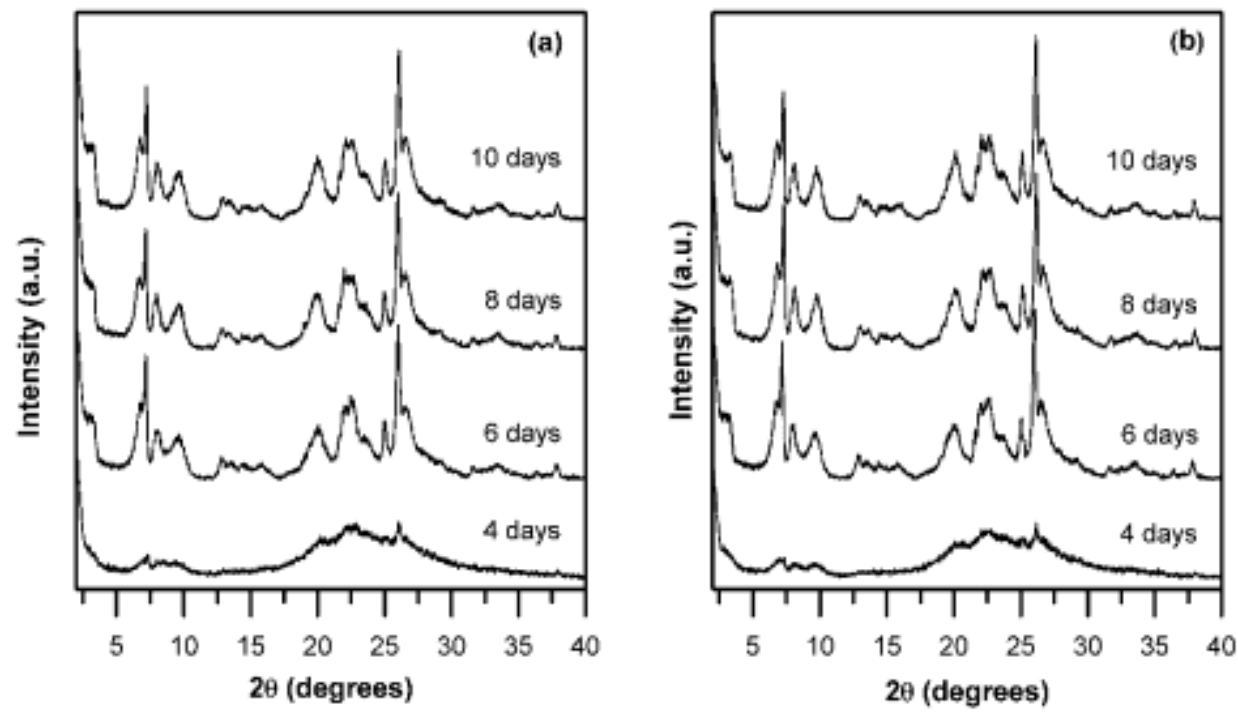

Source: Authors (2021).

The potassium content in the system was then increased to 0.45 and, in this case, the effect on the crystallization kinetics of the precursor was remarkable (Figure 2a). After 4 days it was possible to obtain MCM-22(P) with good crystallinity, evidenced by the already well-resolved diffraction peaks. As the crystallization time increased (6 to 10 days), the peaks became a bit more intense and defined, indicating the formation of slightly more crystalline solids. The increment of the potassium content did not cause impurity formation in the evaluated time interval, demonstrating that the synthesis conditions are very favorable to the MCM-22(P) formation.

The substitution of sodium by potassium in the reaction mixture was further increased $(\mathrm{R}=0.68)$, and the XRD patterns in Figure $2 \mathrm{~b}$ show that the use of mixtures with higher content of $\mathrm{K}^{+}$ions is not suitable for the crystallization of the lamellar precursor. The materials obtained with 4 or 6 days of crystallization are essentially amorphous, and only with 8 days the diffraction peaks began to be detected. The characteristic diffractogram of MCM-22(P) was revealed for the sample synthesized with 10 days of crystallization, but with peaks significantly less intense than those observed for the solids synthesized with lower potassium contents $(\mathrm{R}=0.22$ or 0.45$)$. Following this trend, when $90 \%$ of the $\mathrm{Na}^{+}$ions were replaced by $\mathrm{K}^{+}(\mathrm{R}=0.9)$, only amorphous materials were produced between 4 and 10 days of crystallization. 
Figure 2. XRD patterns of samples synthesized from reaction mixtures with different potassium contents: (a) $R=0.45$ and (b) $\mathrm{R}=0.68$.
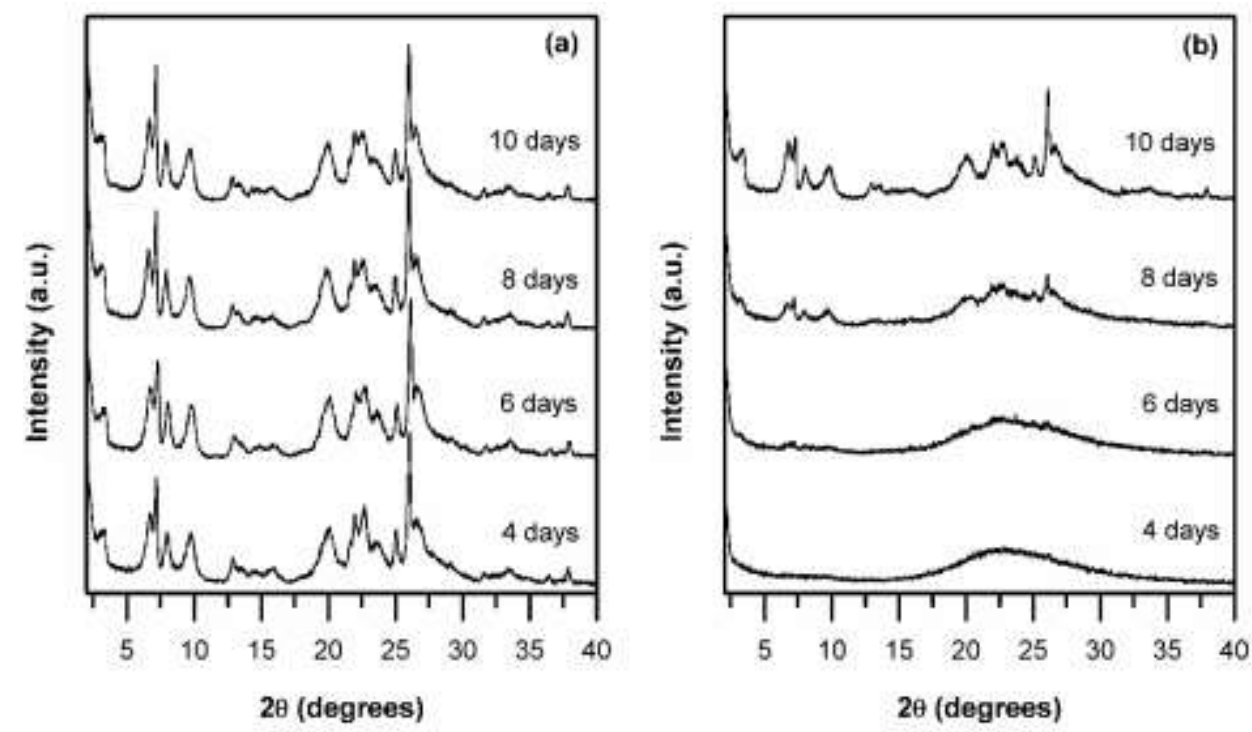

Source: Authors (2021).

The MCM-22(P) samples synthesized with different potassium contents were calcined and their relative crystallinity calculated. Figure 3 illustrates a typical MCM-22 XRD pattern obtained in the present investigation, with more intense and resolved peaks as a result of its greater structural ordering compared to MCM-22(P). The peaks indexed to the crystallographic planes (001) and (002) are not observed in the calcined material, due to the lamellar condensation (Lawton et al., 1996; Shi et al., 2015b).

Figure 3. Typical XRD patterns of MCM-22(P) lamelar precursor and MCM-22 zeolite.

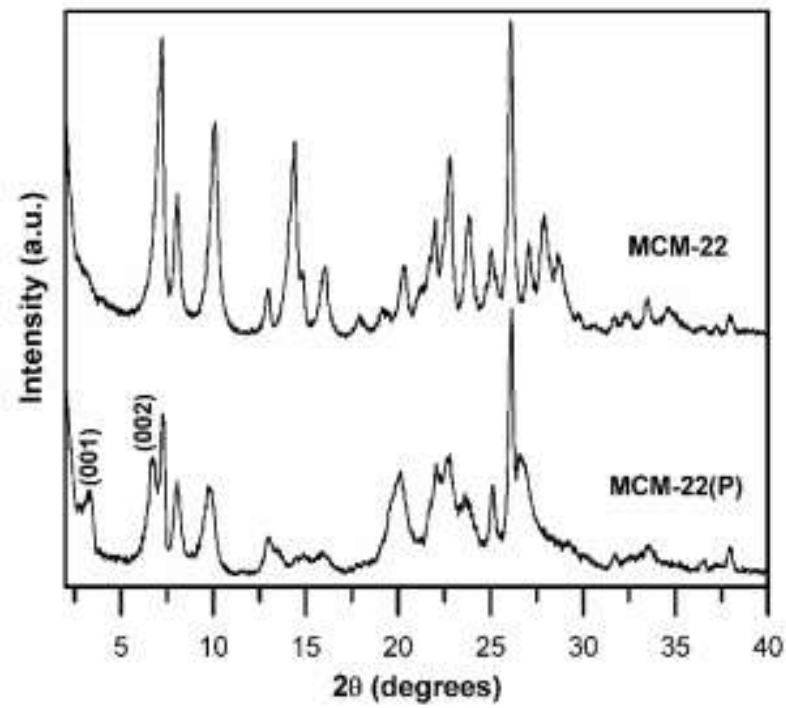

Source: Authors (2021).

Figure 4 shows the MCM-22 crystallization curves of mixtures with different potassium contents. When sodium was the only type of alkali metal present $(\mathrm{R}=0)$ or the substitution of sodium by potassium was low $(\mathrm{R}=0.22)$, the curves exhibited similar trends, with poor crystalline materials being obtained on the fourth day of crystallization, followed by an 
expressive increment in crystallinity. After the sixth day, the crystallinity increased moderately, reaching values around $80 \%$ on the tenth day of crystallization.

The analysis of the curve corresponding to $\mathrm{R}=0.45$ shows that the materials synthesized in this condition are more crystalline than the samples produced with the other values of $\mathrm{R}$, for a same crystallization time. In 6 days, it was possible to prepare MCM-22 with high crystallinity ( 90\%), which gradually increased until reaching $100 \%$ after 10 days of crystallization. On the other hand, it can be observed from the curve associated with $\mathrm{R}=0.68$ that the use of high potassium content in the synthesis increased the induction time and reduced the MCM-22 crystallization rate.

Figure 4. Crystallization curves of MCM-22 zeolite synthesized from reaction mixtures containing different potassium contents (R).

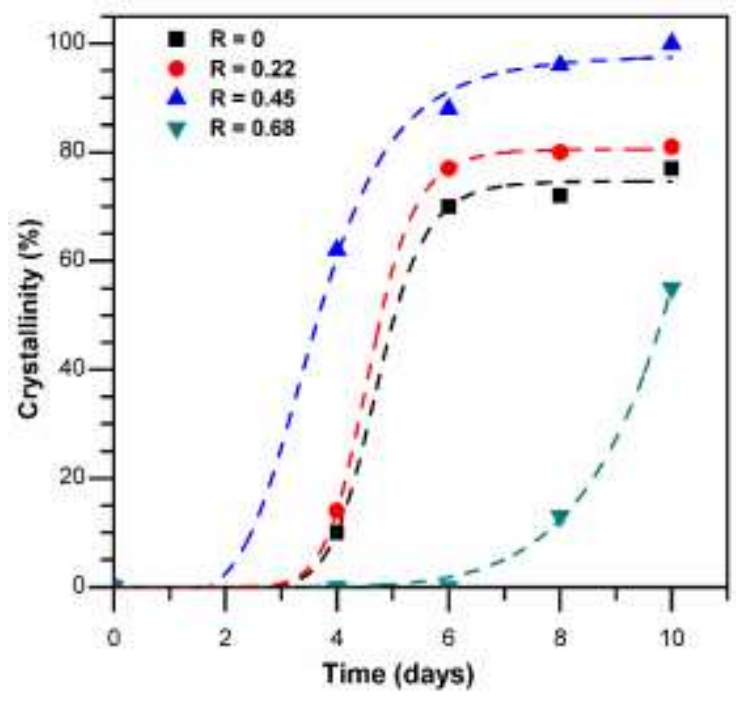

Source: Authors (2021).

These results demonstrate that the simultaneous presence of sodium and potassium in the reaction mixture can modify the MCM-22 crystallization kinetics. However, this modification is only beneficial to the process when the cations are in certain proportions, as already observed in the synthesis of other zeolites (Basaldella \& Tara, 1995; Camblor \& Pérez-Pariente, 1991). The shorter induction period obtained when replacing $45 \%$ of the $\mathrm{Na}^{+}$by $\mathrm{K}^{+}$ions indicates that this condition favored the nucleation of the MWW topology. This observation may be related to the fact that $\mathrm{K}^{+}$ions are selective for the formation of six-membered double rings (D6R), possibly due to the cation charge distribution (Kirschhock et al., 2008). As D6R units are part of the MCM-22 framework, the presence of sufficient amount of potassium in the mixture might enhance nuclei formation. However, the longer induction period observed in the system with $\mathrm{R}=0.68$ suggests that a minimum sodium amount is required for faster a nucleation under the reaction conditions of the present study.

\subsection{Textural properties of MCM-22 samples}

Table I presents the textural properties of the MCM-22 samples obtained from mixtures with different potassium contents and 10 days of crystallization (most crystalline sample for each reaction system investigated). The values obtained are in accordance with the literature for the MCM-22 obtained under static conditions (Carriço et al., 2013; Marques et al., 1999; Wu et al., 2009), except sample 4 due to its low crystallinity. In general, the calculated values for the textural properties 
showed a good correlation with crystallinity, being higher for the more crystalline solids. The reduction in the external area of sample 3 is probably related to its different morphology and higher particle aggregation, as will be further discussed.

Table 1. Textural properties of MCM-22 samples synthesized with different potassium contents and 10 days of crystallization.

\begin{tabular}{|c|c|c|c|c|c|c|}
\hline Sample & $\mathbf{R}$ & $\begin{array}{c}\text { АвET } \\
\left(\mathrm{m}^{2} / \mathrm{g}\right)\end{array}$ & $\begin{array}{c}\text { Aext } \\
\left(\mathbf{m}^{2} / g\right)^{a}\end{array}$ & $\begin{array}{c}V_{\text {total }} \\
\left(\mathrm{cm}^{3} / \mathbf{g}\right)^{\mathbf{b}}\end{array}$ & $\begin{array}{c}V_{\text {micro }} \\
\left(\mathrm{cm}^{3} / \mathbf{g}\right)^{\mathrm{a}}\end{array}$ & $\begin{array}{c}V_{\text {meso }} \\
\left(\mathrm{cm}^{3} / \mathrm{g}\right)^{\mathrm{c}}\end{array}$ \\
\hline 1 & 0 & 424 & 114 & 0.268 & 0.144 & 0.124 \\
\hline 2 & 0.22 & 460 & 114 & 0.274 & 0.16 & 0.114 \\
\hline 3 & 0.45 & 492 & 108 & 0.320 & 0.178 & 0.142 \\
\hline 4 & 0.68 & 304 & 55 & 0.165 & 0.116 & 0.049 \\
\hline
\end{tabular}

The MCM-22 samples showed type $\mathrm{Ib} \mathrm{N}_{2}$ adsorption isotherms (Figure 5), typical of microporous materials that have high external surface area (Rouquerol et al., 2014). In addition, the occurrence of type H3 hysteresis in the isotherms indicates the presence of secondary mesopores due to agglomeration of plate-shaped particles (Leofanti et al., 1998). These observations are in agreement with the external surface area and mesopore volume values summarized in Table I.

Figure 5. $\mathrm{N}_{2}$ adsorption/desorption isotherms of MCM-22 samples synthesized from reaction mixtures containing different potassium contents $(\mathrm{R})$.

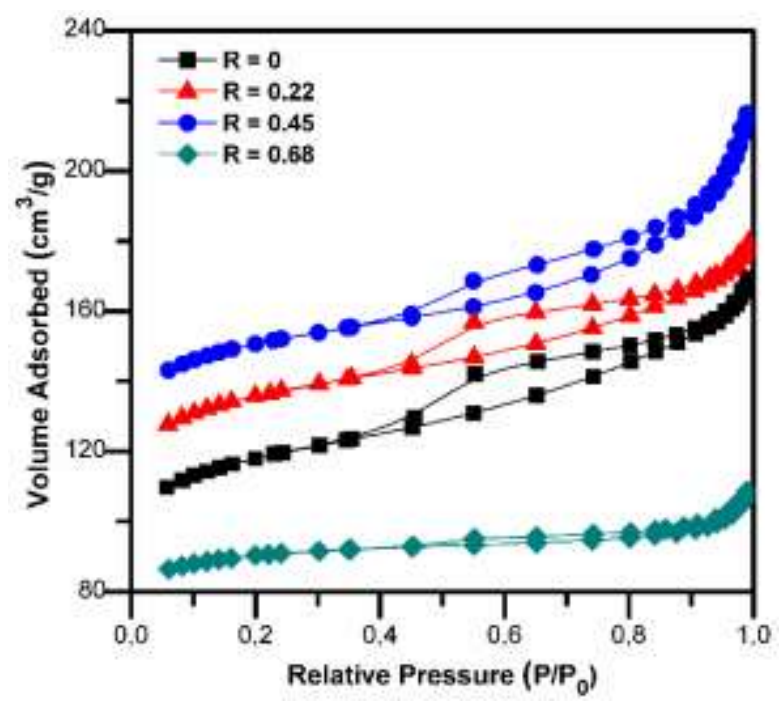

Source: Authors (2021). 


\subsection{Effect of sodium and potassium cations on morphology and particle size}

Figure 6 shows the micrographs of MCM-22 samples synthesized with different potassium content and 10 days of crystallization. The solids obtained in mixtures containing only sodium (sample 1, Figure 6a) or with lower potassium content (sample 2, Figure 6b) showed toroidal morphology with diameter between 6 and $9 \mu \mathrm{m}$, resulting from the stacking of small plates. It can be observed the occurrence of intergrowth in some aggregates and appearance of cracks due to the elimination of the structure-directing agent during the calcination process (Ravishankar et al., 2005).

The particles exhibited different shape and size as the potassium content increased to 0.45 , being formed by plates that agglomerate forming disks with diameter in the range of 3 to $4.5 \mu \mathrm{m}$ and medium thickness of $1 \mu \mathrm{m}$ (sample 3 , Figure $6 \mathrm{c}$ ). The smaller particle sizes observed suggest again that in such condition the $\mathrm{K}^{+}$ions favored the MCM-22 nucleation process, since the formation of a higher number of nuclei reduces the crystal size at the end of the synthesis (Nishi \& Thompson, 2002).

Figure 6. Micrographs of MCM-22 samples obtained from reaction mixtures with different potassium contents: (a) $\mathrm{R}=0$, (b) $\mathrm{R}=0.22,(\mathrm{c}) \mathrm{R}=0.45$ and $(\mathrm{d}) \mathrm{R}=0.68$.
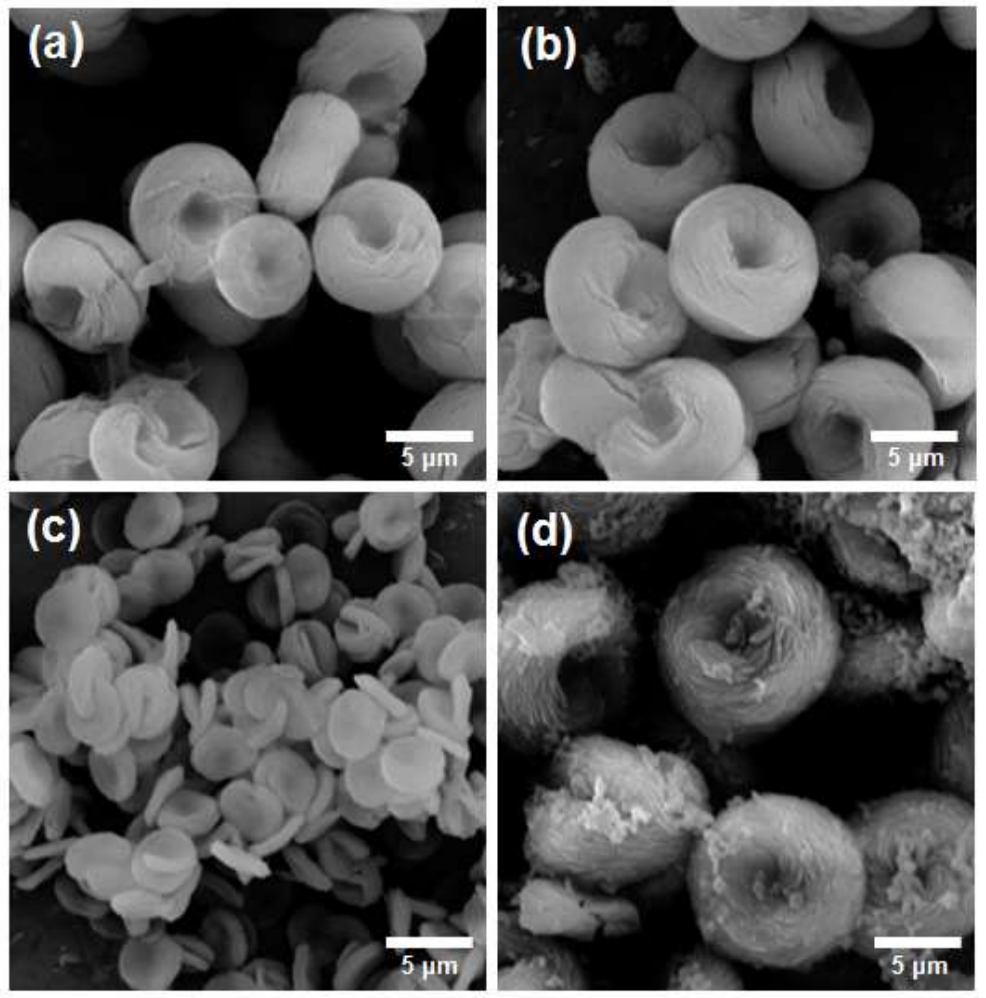

Source: Authors (2021).

The solids synthesized with $\mathrm{R}=0.68$ (sample 4, Figure 6d) also presented toroidal morphology, but with some amorphous material. In this case, the plates did not show the same aggregation level observed in the other samples, indicating that the crystallization process was still at an intermediate stage. Consequently, the particles were obtained with larger diameters, varying from 8 to $11 \mu \mathrm{m}$. 


\section{Conclusion}

The use of reaction mixtures containing sodium and potassium cations in adequate proportions modify the hydrothermal synthesis process of MCM-22 zeolite under static conditions. The substitution of $45 \%$ of $\mathrm{Na}^{+}$by $\mathrm{K}^{+}$decreased the time necessary to obtain the MCM-22(P) precursor and improved the products crystallinity. Furthermore, such modification remarkably influenced the morphology and reduced particle size. These observations suggest that $\mathrm{K}^{+}$ions facilitate MCM-22 nucleation when it is present in sufficient quantity in the reaction mixture. However, the potassium content ranging from 0.68 to 0.9 inhibited MCM-22 synthesis, resulting in the formation of low crystalline or amorphous materials after 10 days of crystallization. This observation indicates that the $\mathrm{Na}^{+}$ions also play an important role in the nucleation and growth of MCM-22 zeolite. In summary, the synthesis of MCM-22 using sodium and potassium cations could be an alternative to produce samples with high crystallinity in a shorter time, reducing the production cost of such zeolite.

For a better understanding of the cooperative effect between sodium and potassium cations in the crystallization of MCM-22 zeolite, it is suggested to evaluate other silicon sources, such as tetraethylorthosilicate (TEOS) and fumed silica, and mixtures with $\mathrm{SiO}_{2} / \mathrm{Al}_{2} \mathrm{O}_{3}$ ratios above 30, keeping the other reaction conditions of the present study the same.

\section{Acknowledgments}

The authors gratefully acknowledge the financial support from PETROBRAS S.A. and CAPES (Brazilian Coordination for Improvement of Higher Education Personnel).

\section{References}

Aiello, R., Crea, F., Testa, F., Demortier, G., Lentz, P., Wiame, M., \& Nagy, J. B. (2000). Synthesis and characterization of aluminosilicate MCM-22 in basic media in the presence of fluoride salts. Microporous and Mesoporous Materials, 35-36, 585-595. https://doi.org/10.1016/S1387-1811(99)00252-8

Basaldella, E. I., \& Tara, J. C. (1995). Synthesis of LSX zeolite in the NaK system: Influence of the NaK ratio. Zeolites, 15(3), 243-246. https://doi.org/10.1016/0144-2449(94)00006-E

Camblor, M. A., \& P6rez-Pariente, J. (1991). Crystallization of zeolite beta: Effect of Na and K ions. Zeolites, 11(3), 202-220. https://doi.org/10.1016/S01442449(05)80220-9

Carriço, C. S., Cruz, F. T., Santos, M. B., Pastore, H. O., Andrade, H. M. C., \& Mascarenhas, A. J. S. (2013). Efficiency of zeolite MCM-22 with different $\mathrm{SiO}_{2} / \mathrm{Al}_{2} \mathrm{O}_{3}$ molar ratios in gas phase glycerol dehydration to acrolein. Microporous and Mesoporous Materials, 181, 74-82. https://doi.org/10.1016/j.micromeso.2013.07.020

Corma, A., Corell, C., \& Pérez-Pariente, J. (1995). Synthesis and characterization of the MCM-22 zeolite. Zeolites, 15(1), 2-8. https://doi.org/10.1016/01442449(94)00013-I

Davis, M. E. (2014). Zeolites from a materials chemistry perspective. Chemistry of Materials, 26, 239-245. https://doi.org/10.1021/cm401914u

Degnan, T. F. (2007). Recent progress in the development of zeolitic catalysts for the petroleum refining and petrochemical manufacturing industries. In R. $\mathrm{Xu}$, Z. Gao, J. Chen, \& W. Yan (Eds.), From Zeolites to Porous MOF Materials: the 40th Anniversary of International Zeolite Conference, Proceedings of the 15th International Zeolite Conference (pp. 54-65). Elsevier. https://doi.org/10.1016/S0167-2991(07)80825-1

Díaz, U., Fornés, V., \& Corma, A. (2006). On the mechanism of zeolite growing: Crystallization by seeding with delayered zeolites. Microporous and Mesoporous Materials, 90(1-3 SPEC. ISS.), 73-80. https://doi.org/10.1016/j.micromeso.2005.09.025

Fechete, I., Wang, Y., \& Védrine, J. C. (2012). The past, present and future of heterogeneous catalysis. Catalysis Today, 189(1), 2-27. https://doi.org/10.1016/J.CATTOD.2012.04.003

Güray, I., Warzywoda, J., Baç, N., \& Sacco, A. (1999). Synthesis of zeolite MCM-22 under rotating and static conditions. Microporous and Mesoporous Materials, 31, 241-251. https://doi.org/10.1016/S1387-1811(99)00075-X

Khaleque, A., Alam, M. M., Hoque, M., Mondal, S., Haider, J. B., Xu, B. Johir, M. A. H., Karmakar, A. K., Zhou, J. L., Ahmed, M. B., \& Moni, M. A. (2020). Zeolite synthesis from low-cost materials and environmental applications: A review. Environmental Advances, 2 , Article 100019. https://doi.org/10.1016/J.ENVADV.2020.100019

Kirschhock, C. E. A., Feijen, E. J. P., Jacobs, P. A., \& Martens, J. A. (2008). Hydrothermal Zeolite Synthesis. In G. Ertl, H. Knözinger, F. Schüth, \& J. Weitkamp (Eds.), Handbook of Heterogeneous Catalysis (2nd ed., pp. 160-178). Wiley-VCH Verlag GmbH \& Co. KGaA. https://doi.org/10.1002/9783527610044.hetcat0010 
Laredo, G. C., Quintana-Solórzano, R., Castillo, J. J., Armendáriz-Herrera, H., \& Garcia-Gutierrez, J. L. (2013). Benzene reduction in gasoline by alkylation with propylene over MCM-22 zeolite with a different Brønsted/Lewis acidity ratios. Applied Catalysis A: General, 454, 37-45. https://doi.org/10.1016/j.apcata.2013.01.001

Lawton, S. L., Leonowicz, M. E., Partridge, R. D., Chu, P., \& Rubin, M. K. (1998). Twelve-ring pockets on the external surface of MCM-22 crystals. Microporous and Mesoporous Materials, 23(1-2), 109-117. https://doi.org/10.1016/S1387-1811(98)00057-2

Lawton, S. L, Fung, A. S., Kennedy, G. J., Alemany, L. B., Chang, C. D., Hatzikos, G. H., Lissy, D. N., Rubin, M. K., Timken, H. C., Steuernagel, S., Woessner, D. E. (1996). Zeolite MCM-49: A Three-Dimensional MCM-22 Analogue Synthesized by in Situ Crystallization. The Journal of Physical Chemistry, 100, 3788-3798. https://doi.org/10.1021/jp952871e

Leofanti, G., Padovan, M., Tozzola, G., \& Venturelli, B. (1998). Surface area and pore texture of catalysts. Catalysis Today, 41, 207-219. https://doi.org/10.1016/S0920-5861(98)00050-9

Li, Y., \& Yu, J. (2021). Emerging applications of zeolites in catalysis, separation and host-guest assembly. Nature Reviews Materials. https://doi.org/10.1038/s41578-021-00347-3

Marques, A. L. S., S., Monteiro, J. L. F., \& Pastore, H. O. (1999). Static crystallization of zeolites MCM-22 and MCM-49. Microporous and Mesoporous Materials, 32, 131-145. https://doi.org/10.1016/S1387-1811(99)00099-2

Nishi, K., \& Thompson, R. W. (2002). Synthesis of Classical Zeolites. In F. Schüth, K. S. W. Sing, \& J. Weitkamp (Eds.), Handbook of Porous Solids (pp. 736-814). Wiley-VCH Verlag GmbH. https://doi.org/10.1002/9783527618286.ch18a

Ravishankar, R., Li, M. M., \& Borgna, A. (2005). Novel utilization of MCM-22 molecular sieves as supports of cobalt catalysts in the Fischer-Tropsch synthesis. Catalysis Today, 106(1-4), 149-153. https://doi.org/10.1016/j.cattod.2005.07.123

Roth, W. J., Chlubná, P., Kubů, M., \& Vitvarová, D. (2013). Swelling of MCM-56 and MCM-22P with a new medium - Surfactant- tetramethylammonium hydroxide mixtures. Catalysis Today, 204, 8-14. https://doi.org/10.1016/j.cattod.2012.07.040

Rouquerol, F., Rouquerol, J., Sing, K. S. W., Llewellyn, P., Maurin. (2014). Adsorption by Powders and Porous Solids: Principles, Methodology and Applications (2nd ed.). https://doi.org/10.1016/C2010-0-66232-8

Shi, J., Wang, Y., Yang, W., Tang, Y., \& Xie, Z. (2015a). Recent advances of pore system construction in zeolite-catalyzed chemical industry processes. Chemical Society Reviews, 44, 8877-8903. Royal Society of Chemistry. https://doi.org/10.1039/c5cs00626k

Shi, Y., Xing, E., Xie, W., Zhang, F., Mu, X., \& Shu, X. (2015b). Directing gel: An effective method tailoring morphology of MWW zeolites and their catalytic performance in liquid-phase alkylation of benzene with ethylene. Microporous and Mesoporous Materials, 215, 5-18. https://doi.org/10.1016/j.micromeso.2015.04.041

Sig Ko, Y., \& Seung Ahn, W. (2004). Crystallization of zeolite L from $\mathrm{Na}_{2} \mathrm{O}-\mathrm{K}_{2} \mathrm{O}-\mathrm{Al}_{2} \mathrm{O}_{3}-\mathrm{SiO}_{2}-\mathrm{H}_{2} \mathrm{O}$ system. Powder Technology, 145(1), 10-19. https://doi.org/10.1016/j.powtec.2004.03.016

Suzuki, Y., Wakihara, T., Itabashi, K., Ogura, M., \& Okubo, T. (2009). Cooperative effect of sodium and potassium cations on synthesis of ferrierite. Topics in Catalysis, 52(1-2), 67-74. https://doi.org/10.1007/s11244-008-9136-6

Vuono, D., Pasqua, L., Testa, F., Aiello, R., Fonseca, A., Korányi, T. I., \& Nagy, J. B. (2006). Influence of NaOH and KOH on the synthesis of MCM-22 and MCM-49 zeolites. Microporous and Mesoporous Materials, 97(1-3), 78-87. https://doi.org/10.1016/j.micromeso.2006.07.015

Wu, Y., Ren, X., Lu, Y., \& Wang, J. (2008). Crystallization and morphology of zeolite MCM-22 influenced by various conditions in the static hydrothermal synthesis. Microporous and Mesoporous Materials, 112(1-3), 138-146. https://doi.org/10.1016/j.micromeso.2007.09.022

Wu, Y., Ren, X., \& Wang, J. (2009). Facile synthesis and morphology control of zeolite MCM-22 via a two-step sol-gel route with tetraethyl orthosilicate as silica source. Materials Chemistry and Physics, 113(2-3), 773-779. https://doi.org/10.1016/J.MATCHEMPHYS.2008.08.008 